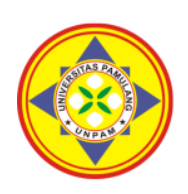

\title{
PENGARUH MOTIVASI DAN DISIPLIN KERJA TERHADAP KINERJA PEGAWAI PADA DINAS PARIWISATA PURWAKARTA
}

\author{
${ }^{1 *}$ Lily Setyawati Kristianti, ${ }^{2}$ Azhar Affandi, ${ }^{3}$ Nurjaya, ${ }^{4}$ Denok Sunarsi, ${ }^{5}$ Achmad Rozi \\ 1.4.Universitas Pamulang, Tangerang, Banten, Indonesia \\ 2Universitas Pasundan, Bandung, Jawa Barat, Indonesia \\ ${ }^{3}$ Universitas Suryakancana, Cianjur, Jawa Barat, Indonesia \\ ${ }^{5}$ Universitas Primagraha, Serang, Banten, Indonesia \\ *dosen02521@unpam.ac.id
}

\begin{abstract}
Abstrak
Penelitian ini bertujuan untuk mengetahui pengaruh motivasi dan disiplin kerja terhadap kinerja pegawai pada Dinas Pariwisata Purwakarta. Metode yang digunakan adalah explanatory research dengan teknik analisis menggunakan analisis statistik dengan pengujian regresi, korelasi, determinasi dan uji hipotesis. Hasil penelitian ini motivasi berpengaruh signifikan terhadap kinerja pegawai sebesar $42,4 \%$, uji hipotesis diperoleh thitung $>t$ tabel atau $(7,071>1,995)$. Disiplin kerja berpengaruh signifikan terhadap kinerja pegawai sebesar 42,7\%, uji hipotesis diperoleh $t$ hitung $>t$ tabel atau $(7,112>1,995)$. Motivasi dan disiplin kerja secara simultan berpengaruh signifikan terhadap kinerja pegawai dengan persamaan regresi $Y=8,586+0,387 \mathrm{X} 1+0,405 \mathrm{X} 2$ dan kontribusi pengaruh sebesar $56,7 \%$, uji hipotesis diperoleh $\mathrm{F}$ hitung $>\mathrm{F}$ tabel atau $(43,928>2,740)$.
\end{abstract}

Kata Kunci: Motivasi, Disiplin kerja, Kinerja Pegawai.

Abstract

This study aims to determine the effect of motivation and work discipline on employee performance at the Purwakarta Tourism Office. The method used is explanatory research with analysis techniques using statistical analysis with regression testing, correlation, determination and hypothesis testing. The results of this study, motivation has a significant effect on employee performance by $42.4 \%$, the hypothesis test obtained $t$ count $>t$ table or $(7,071>1,995)$. Work discipline has a significant effect on employee performance by $42.7 \%$, hypothesis testing is obtained $t$ count $>t$ table or $(7,112>1,995)$. Motivation and work discipline simultaneously have a significant effect on employee performance with the regression equation $Y=8,586+0.387 \mathrm{X} 1+0.405 \mathrm{X} 2$ and the contribution of the effect is $56.7 \%$, hypothesis testing is obtained F count $>F$ table or $(43.928>2.740)$.

Keywords: Motivation, Work Discipline, Employee Performance.

\section{PENDAHULUAN}

Sumber daya manusia merupakan penggerak utama jalannya kegiatan sebuah organisasi, maju mundurnya suatu organisasi ditentukan oleh keberadaan sumber daya manusianya. Sehingga sumber daya manusia atau pegawai dalam sebuah organisasi menjadi perhatian penting dalam rangka usaha mencapai keberhasilan organisasi.

Keberhasilan suatu organisasi dalam mencapai tujuan organisasi ditentukan oleh kinerja pegawai. Kemampuan pegawai mengerjakan pekerjaan yang menjadi tanggung jawabnya menjadi tolok ukur pencapaian tujuan organisasi. Apabila suatu organisasi mampu mencapai tujuan yang telah ditetapkan, maka dapat dikatakan bahwa organisasi tersebut efektif. Seiring dengan berkembangnya waktu, semua organisasi dituntut untuk dapat bersaing memberikan pelayanan yang terbaik, termasuk organisasi pemerintah.

Pelayanan yang terbaik, tidak dapat dilepaskan dari peran setiap pegawainya. Seorang pegawai harus bisa bekerja secara optimal dimana hal ini dapat dilihat atau diukur melalui kinerja pegawai tersebut. Menurut Mangkunegara (2017), berpendapat bahwa kinerja adalah hasil 
kerja secara kualitas dan kuantitas yang dicapai oleh seorang pegawai dalam melaksanakan tugasnya sesuai dengan tanggung jawab yang diberikan kepadanya.

Kinerja yang baik adalah kinerja yang optimal, yaitu kinerja yang sesuai standar organisasi dan mendukung tercapainya tujuan organisasi. Peningkatan kinerja pegawai akan membawa kemajuan bagi instansi (organisasi) untuk dapat bertahan dalam suatu persaingan yang tidak stabil. Kinerja pegawai dipengaruhi oleh beberapa faktor baik yang berhubungan dengan tenaga kerja itu sendiri maupun yang berhubungan dengan lingkungan perusahaan atau organisasi. Wexley dan Yukl (2005), mengidentifikasi faktor-faktor yang mempengaruhi kinerja antara lain adalah motivasi dan disiplin kerja.

Dinas Pariwisata Purwakarta merupakan unsur pelaksana Otonomi daerah, yang mempunyai tugas menyelenggarakan kewenangan desentralisasi dan dekonsentrasi di bidang pariwisata dan juga sebagai suatu organisasi pemerintah yang mengemban tugas meningkatkan kesejahteraan masyarakat melalui peningkatan ketersediaan kebutuhan masyarakat umum, yaitu ketersediaan hasil-hasil pariwisata yang menjadi kebutuhan pokok manusia lebih khusus kebutuhan masyarakat yang ada disekitar atau yang masuk dalam lingkup pelayanan dinas pariwisata ini, sehingga sesuai dengan Keputusan Menteri Negara Pendayagunaan Aparatur Negara (Meneg PAN) Nomor 63/KEP/M.PAN/7/2003, memberikan pengertian pelayanan publik yaitu segala kegiatan pelayanan yang dilaksanakan oleh penyelenggara pelayanan publik sebagai upaya pemenuhan kebutuhan penerima pelayanan maupun pelaksanaan ketentuan peraturan perundang-undangan.

Pelayanan yang diberikan oleh dinas pariwisata sangat dipengaruhi oleh keberadaan dari sumber daya manusia atau pegawai-pegawai yang ada didalam dinas tersebut. Pegawai Dinas pariwisata Purwakarta saat ini dipimpin oleh Kepala Dinas, didampingi Sekretaris Dinas, Kepala Bidang, Kasubbag, Kasie serta staffstaffnya. Menurut Mc Clelland dalam Mangkunegara, (2017) seorang pegawai dikatakan memiliki motivasi kerja yang tinggi apabila, didalam dirinya memiliki: (1) need of achievement (kebutuhan berprestasi) yaitu kemampuan pegawai (2) Need of affiliation (kebutuhan afiliasi) yaitu keinginan pegawai untuk saling bersahabat dan mengenal lebih jauh teman kerja dalam sebuah organisasi pemerintahan, dan (3) need of power (kebutuhan kekuasaan) yaitu kebutuhan yang membuat pegawai berperilaku wajar dalam melaksanakan tugasnya serta keinginan untuk menguasai sesuatu, akan tetapi dalam hal ini instansi belum maksimal memberikan dorongan atau motivasi pada para pegawai pada dinas pariwisata Purwakarta, kurangya perhatian dari atasan terhadap bawahan, hal ini diduga penyebab dari pegawai tidak memiliki keinginan ataupun dorongan untuk mencapai kinerja yang melebihi standar yang telah ditetapkan.

Sementara disiplin kerja adalah suatu sikap, perilaku yang dilakukan secara sukarela dan penuh kesadaran serta keadaan untuk mengikuti peraturan yang telah ditetapkan instansi baik tertulis maupun tidak tertulis (Nitisemito, 2002). Tanpa disiplin pegawai yang baik, sulit bagi organisasi perusahaan atau instansi mencapai hasil yang optimal. Seorang Pegawai yang mempunyai tingkat kedisiplinan yang tinggi akan tetap bekerja dengan baik walaupun tanpa diawasi oleh atasan, tidak akan mencuri waktu kerja untuk melakukan hal-hal lain yang tidak ada kaitannya dengan pekerjaan, akan mentaati peraturan yang ada dalam lingkungan kerja dengan kesadaran yang tinggi tanpa ada rasa paksaan. 
Disiplin kerja dapat mempengaruhi kinerja pegawai, pernyataan ini diperkuat dengan adanya pendapat dari Malayu S.P Hasibuan (2017) "Semakin baik disiplin kerja seseorang, maka semakin tinggi hasil prestasi kerja (kinerja) yang akan dicapai". Disiplin kerja pegawai dinas pariwisata Purwakarta bisa dilihat dari tingkat kehadiran dan ketepatan waktu datang ke kantor. Hal ini bisa dilihat dari tingkat absensi yang dicapai. Metode absensi di kantor dinas pariwisata Purwakarta menggunakan sidik jari (finger), sehingga bisa tepat dan akurat dalam hal menilai kedisplinan para pegawai.

Menurunnya kinerja pegawai dapat disebabkan oleh rendahnya dorongan dalam diri sendiri untuk bekerja sama, bekerja efektif dalam mencapai tujuan. Kurangnya perhatian atasan kepada bawahan juga menyebabkan motivasi pegawai di Dinas pariwisata Purwakarta rendah. Pegawai lebih suka melimpahkan tugas yang sudah menjadi tanggung jawab mereka kepada pegawai kontrak sehingga keinginan untuk memotivasi diri sendiri belum maksimal, dan juga atasan kurang intens dalam memberikan motivasi kepada pegawai bawahannya, sehingga berdampak rendahnya semangat kerja pegawai, karena merasa kurang diperhatikan dan mengakibatkan kinerja pegawai menjadi tidak optimal.

Faktor lain yang menyebabkan menurunnya kinerja pegawai dinas pariwisata Purwakarta adalah lingkungan kerja fisik yang kurang mendukung produktivitas kerja, yaitu ruangan kerja yang gelap, saling terbuka dan berdempetan sehingga pegawai merasa sempit. Beberapa pegawai juga menyebutkan menurunnya kinerja disebabkan adanya beban kerja yang tinggi dan minimnya penghargaan yang diberikan atas kinerja yang dicapai oleh para pegawai. Tingkat disiplin kerja pegawai dan motivasi pegawai akan sangat mempengaruhi kinerja pegawai dan berpengaruh terhadap produktivitas sebuah instansi pemerintahan. Instansi tidak dapat berjalan dengan baik bila pengelolaan pegawai dalam kedisplinan dan motivasi terhadap pegawai tidak dikelola dengan sebaik-baiknya. Kondisi di atas menimbulkan permasalahan dalam pencapaian kinerja pegawai. Pencapaian kinerja yang belum optimal diduga dikarenakan kurangnya disiplin kerja pegawai dan rendahnya motivasi. Berdasarkan latar belakang diatas, maka penelitian ini diberi judul "Pengaruh Motivasi dan Disiplin Kerja terhadap Kinerja Pegawai pada Dinas pariwisata Purwakarta".

\section{TINJAUAN PUSTAKA}

1. Motivasi

Menurut Maslow dalam Sutrisno (2017:55), menyatakan bahwa motivasi adalah pemberian daya penggerak yang menciptakan kegairahan kerja seseorang, agar mereka mau bekerja sama, bekerja efektif dan terintegrasi dengan segala upayanya untuk mencapai kepuasan dalam bekerja.

2. Disiplin kerja

Menurut Sutrisno (2016) mendefinisikan "Disiplin adalah perilaku seseorang yang sesuai dengan peraturan, prosedur kerja yang ada atau sikap dan tingkah laku serta perbuatan yang sesuai dengan peraturan dari organisasi baik tertulis maupun tidak tertulis". Dalam penelitian ini indikator yang digunakan meliputi: taat terhadap aturan waktu taat terhadap aturan organisasi, taat terhadap aturan perilaku dalam pekerjaan, taat terhadap peraturan lainnya.

3. Kinerja Pegawai

Dalam melaksanakan suatu pekerjaan, perusahaan perlu melakukan penilaian kinerja (performance appraisal) agar dapat diketahui efektifitas dan keberhasilan kinerja yang dilakukan karyawan. Menurut Mathis dan Jackson (2016:61) berpendapat "Penilaian kinerja merupakan proses 
mengevaluasi seberapa baik karyawan melakukan pekerjaan mereka jika dibandingkan dengan seperangkat standar, dan kemudian mengokmunikasikan informasi tersebut kepada karyawan". Menurut Thomas dan Scott dalam Hasibuan (2016:28) berpendapat "Penilaian kinerja adalah penilaian dari kinerja jabatan seseorang karyawan, dimana merupakan salah satu tanggung jawab paling penting yang ada pada seorang manajer".

\section{METODE}

Populasi dalam penelitian ini berjumlah 70 responden Dinas Pariwisata Purwakarta. Teknik pengambilan sampling dalam penelitian ini adalah samplel jenuh, dimana semua anggota populasi dijasikan sebagai sampel. Dengan demikian sampel dalam penelitian ini berjumlah 70 responden. Jenis penelitian yang dipakai adalah asosiatif, dimana tujuannya adalah untuk mengetahui pengaruh antara variabel bebas terhadap variabel terikat baik parsial maupun simultan Dalam menganalisis data digunakan uji instrumen, uji asumsi klasik, regresi, koefisien determinasi dan uji hipotesis.

\section{HASIL DAN PEMBAHASAN}

1. Analisis Deskriptif

Pada pengujian ini digunakan untuk mengetahui skor minimum dan maksimum, mean score dan standar deviasi dari masing-masing variabel. Adapun hasilnya sebagai berikut:

Tabel 1. Hasil Analisis Descriptive Statistics

Descriptive Statistics

$\mathrm{N}$ Minimum Maximum Mean Std. Deviation

\begin{tabular}{|l|r|r|r|r|r|}
\hline Motivasi (X1) & 70 & 31 & 48 & 37.47 & 4.078 \\
\hline Disiplin kerja (X2) & 70 & 28 & 45 & 37.47 & 3.937 \\
\hline Kinerja Pegawai (Y) & 70 & 31 & 47 & 38.27 & 3.647 \\
\hline Valid N (listwise) & 70 & & & & \\
\hline
\end{tabular}

2. Analisis Verifikatif

Pada analisis ini dimaksudkan untuk mengetahui pengaruh variabel independen terhadap variabel dependen. Adapun hasil pengujian sebagai berikut: a. Analisis Regresi Linier Berganda

Uji regresi ini dimaksudkan untuk mengetahui perubahan variabel dependen jika variabel independen mengalami perubahan. Adapun hasil pengujiannya sebagai berikut:

Tabel 2. Hasil Pengujian Regresi Linier Berganda

\section{Coefficientsa}

Unstandardized Coefficients Standardized Coefficients

\begin{tabular}{l|r|r|r|r|r} 
Model & B & Std. Error & Beta & $\mathrm{t}$ & Sig. \\
\hline 1 (Constant) & 8.586 & 3.182 & & 2.699 & .009 \\
\hline Motivasi (X1) & .387 & .083 & .433 & 4.670 & .000 \\
\hline Disiplin kerja (X2) & .405 & .086 & .437 & 4.715 & .000 \\
\hline
\end{tabular}

a. Dependent Variable: Kinerja Pegawai (Y)

Berdasarkan hasil pengujian pada tabel di atas, diperoleh persamaan regresi $Y=8,586+0,387 X 1$ $+0,405 X 2$. Dari persamaan tersebut dijelaskan sebagai berikut:

1) Konstanta sebesar 8,586 diartikan jika motivasi dan disiplin kerja tidak ada, maka telah terdapat nilai kinerja pegawai sebesar 8,586 point.

2) Koefisien regresi motivasi sebesar 0,387, angka ini positif artinya setiap ada peningkatan motivasi sebesar 0,387 maka kinerja pegawai juga akan mengalami peningkatan sebesar 0,387 point. 
3) Koefisien regresi disiplin kerja sebesar 0,405, angka ini positif artinya setiap ada peningkatan disiplin kerja sebesar 0,405 maka kinerja pegawai juga akan mengalami peningkatan sebesar 0,405 point. b. Analisis Koefisien Korelasi

Analisis koefisien korelasi dimaksudkan untuk mengetahui tingkt kekuatan hubungan dari variabel independen terhadap variabel dependen baik secara parsial maupun simultan. Adapun hasil pengujian sebagai berikut:

Tabel 3. Hasil Pengujian Koefisien Korelasi Motivasi Terhadap Kinerja Pegawai. Correlations $^{\mathrm{b}}$

\begin{tabular}{llr|r} 
& \multicolumn{2}{r}{ Motivasi (X1) } & Kinerja Pegawai (Y) \\
\hline Motivasi (X1) & Pearson Correlation & 1 & $.651^{* *}$ \\
\cline { 2 - 4 } & Sig. (2-tailed) & & .000 \\
\hline Kinerja Pegawai (Y) & Pearson Correlation & $.651^{* *}$ & 1 \\
\cline { 2 - 4 } & Sig. (2-tailed) & .000 & \\
\hline
\end{tabular}

Berdasarkan hasil pengujian diperoleh nilai korelasi sebesar 0,651

Tabel 4. Hasil Pengujian Koefisien Korelasi Disiplin kerja Terhadap Kinerja Pegawai.

\section{Correlations $^{b}$} Disiplin kerja (X2) Kinerja Pegawai (Y)

\begin{tabular}{llr|r}
\hline Disiplin kerja (X2) & Pearson Correlation & 1 & $.653^{\text {** }}$ \\
\cline { 2 - 4 } & Sig. (2-tailed) & & .000 \\
\hline Kinerja Pegawai (Y) & Pearson Correlation & $.653^{* *}$ & 1 \\
\cline { 2 - 4 } & Sig. (2-tailed) & .000 & \\
\hline
\end{tabular}

Berdasarkan hasil pengujian diperoleh nilai korelasi sebesar 0,653 artinya disiplin kerja memiliki hubungan yang kuat terhadap kinerja pegawai.

Tabel 5. Hasil Pengujian Koefisien Korelasi Motivasi dan Disiplin kerja secara simultan Terhadap Kinerja Pegawai.

Model Summary

\begin{tabular}{ll|l|l|l|} 
Model & $R$ & R Square & Adjusted R Square & Std. Error of the Estimate \\
\hline 1
\end{tabular}

\begin{tabular}{lrrrr}
\hline 1 & $.753^{\mathrm{a}}$ & .567 & .554 & 2.435 \\
\hline a. Predictors: (Constant), Disiplin kerja (X2), Motivasi (X1)
\end{tabular}

Berdasarkan hasil pengujian diperoleh nilai korelasi sebesar 0,753 artinya motivasi dan disiplin kerja secara simultan memiliki hubungan yang kuat terhadap kinerja pegawai.

c. Analisis Koefisien Determinasi
Analisis koefisien determinasi dimaksudkan untuk mengetahui besarnya persentase pengaruh dari variabel independen terhadap variabel dependen baik secara parsial maupun simultan. Adapun hasil pengujian sebagai berikut:

Tabel 6. Hasil Pengujian Koefisien Determinasi Motivasi Terhadap Kinerja Pegawai. Model Summary ModelR R SquareAdjusted R SquareStd. Error of the Estimate

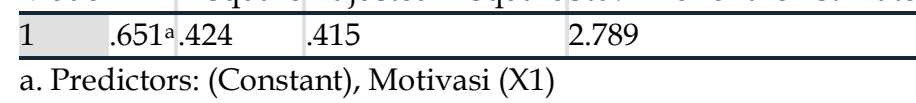

Berdasarkan hasil pengujian diperoleh nilai determinasi sebesar 0,424 artinya motivasi memiliki kontribusi pengaruh sebesar $42,4 \%$ terhadap kinerja pegawai. 
Tabel 7. Hasil Pengujian Koefisien Determinasi Disiplin kerja Terhadap Kinerja Pegawai.

\begin{tabular}{lr|r|r|r} 
Model & $\mathrm{R}$ & $\mathrm{R}$ Square & $\begin{array}{c}\text { Model Summary } \\
\text { Adjusted R Square }\end{array}$ & Std. Error of the Estimate \\
\hline 1 & $.653^{\mathrm{a}}$ & .427 & .418 & 2.782 \\
\hline a. Predictors: (Constant), Disiplin kerja (X2)
\end{tabular}

Berdasarkan hasil pengujian diperoleh nilai determinasi sebesar 0,427 artinya disiplin kerja memiliki kontribusi pengaruh sebesar $42,7 \%$ terhadap kinerja pegawai.

Tabel 8. Hasil Pengujian Koefisien Determinasi Motivasi dan Disiplin kerja Terhadap Kinerja Pegawai. Model Summary

\begin{tabular}{lr|r|r|r} 
Model & $\mathrm{R}$ & R Square & Adjusted R Square & Std. Error of the Estimate \\
\hline 1 & $.753 \mathrm{a}$ & .567 & .554 & 2.435 \\
\hline
\end{tabular}

a. Predictors: (Constant), Disiplin kerja (X2), Motivasi (X1)

Berdasarkan hasil pengujian diperoleh nilai determinasi sebesar 0,567 artinya motivasi dan disiplin kerja secara simultan memiliki kontribusi pengaruh sebesar 56,7\% terhadap kinerja pegawai, sedangkan sisanya sebesar $43,3 \%$ dipengaruhi faktor lain

\section{d. Uji Hipotesis}

Uji hipotesis Parsial (Uji t)

Pengujian hipotesis dengan uji $t$ digunakan untuk mengetahui hipotesis parsial mana yang diterima. Hipotesis pertama: Terdapat pengaruh yang signifikan antara motivasi terhadap kinerja pegawai.

Tabel 9. Hasil Uji Hipotesis Motivasi Terhadap Kinerja Pegawai.

\section{Coefficientsa}

Unstandardized Coefficients Standardized Coefficients

\begin{tabular}{|c|c|c|c|c|c|}
\hline Model & $\mathrm{B}$ & Std. Error & Beta & $\mathrm{t}$ & Sig. \\
\hline 1 (Constant) & 16.456 & 3.103 & & 5.303 & .000 \\
\hline Motivasi (X1) & .582 & .082 & .651 & 7.071 & .000 \\
\hline
\end{tabular}

a. Dependent Variable: Kinerja Pegawai $(\mathrm{Y})$

Berdasarkan hasil pengujian pada tabel di atas, diperoleh nilai $t$ hitung $>\mathrm{t}$ tabel atau $(7,071>1,995)$, dengan demikian hipotesis pertama yang diajukan bahwa terdapat pengaruh yang signifikan atara motivasi terhadap kinerja pegawai diterima.

Tabel 10. Hasil Uji Hipotesis Disiplin kerja Terhadap Kinerja Pegawai

\section{Coefficients ${ }^{a}$}

Unstandardized Coefficients Standardized Coefficients

\begin{tabular}{|c|c|c|c|c|c|}
\hline Model & B & Std. Error & Beta & $\mathrm{t}$ & Sig. \\
\hline 1 (Constant) & 15.600 & 3.205 & & 4.867 & .000 \\
\hline Disiplin kerja $(\mathrm{X} 2)$ & .605 & .085 & .653 & 7.112 & .000 \\
\hline
\end{tabular}

a. Dependent Variable: Kinerja Pegawai (Y)

Berdasarkan hasil pengujian pada tabel di atas, diperoleh nilai $\mathrm{t}$ hitung $>\mathrm{t}$ tabel atau $(7,112>1,995)$, dengan demikian hipotesis kedua yang diajukan bahwa terdapat pengaruh yang signifikan atara disiplin kerja terhadap kinerja pegawai diterima.

Uji Hipotesis Simultan (Uji F)
Pengujian hipotesis dengan uji $\mathrm{F}$ digunakan untuk mengetahui hipotesis simultan yang mana yang diterima.

Hipotesis ketiga Terdapat pengaruh yang signifikan antara motivasi dan disiplin kerja terhadap kinerja pegawai. 
Tabel 11. Hasil Uji Hipotesis Motivasi dan Disiplin kerja Terhadap Kinerja Pegawai.

ANOVA $^{a}$

\begin{tabular}{|c|c|c|c|c|c|}
\hline Model & Sum of Squares & $\mathrm{df}$ & Mean Square & $\mathrm{F}$ & Sig. \\
\hline 1 Regression & 520.729 & 2 & 260.364 & 43.928 & $.000^{\mathrm{b}}$ \\
\hline Residual & 397.114 & 67 & 5.927 & & \\
\hline Total & 917.843 & 69 & & & \\
\hline
\end{tabular}

Berdasarkan hasil pengujian pada tabel di atas, diperoleh nilai $\mathrm{F}$ hitung > F tabel atau $(43,928>2,740)$, dengan demikian hipotesis ketiga yang diajukan bahwa terdapat pengaruh yang signifikan atara motivasi dan disiplin kerja terhadap kinerja pegawai diterima.

\section{PEMBAHASAN HASIL PENELITIAN}

\section{Pengaruh Motivasi Terhadap Kinerja} Pegawai

Motivasi berpengaruh signifikan terhadap kinerja pegawai dengan korelasi sebesar 0,651 atau memiliki hubungan yang kuat dengan kontribusi pengaruh sebesar $42,4 \%$. Pengujian hipotesis diperoleh nilai $\mathrm{t}$ hitung $>\mathrm{t}$ tabel atau $(7,071>1,995)$. Dengan demikian hipotesis pertama yang diajukan bahwa terdapat berpengaruh signifikan antara motivasi terhadap kinerja pegawai diterima.

2. Pengaruh Disiplin kerja Terhadap Kinerja Pegawai

Disiplin kerja berpengaruh signifikan terhadap kinerja pegawai dengan korelasi sebesar 0,653 atau memiliki hubungan yang kuat dengan kontribusi pengaruh sebesar 42,7\%. Pengujian hipotesis diperoleh nilai thitung $>\mathrm{t}$ tabel atau $(7,112>1,995)$. Dengan demikian hipotesis kedua yang diajukan bahwa terdapat berpengaruh signifikan antara disiplin kerja terhadap kinerja pegawai diterima.

3. Pengaruh Motivasi dan Disiplin kerja Terhadap Kinerja Pegawai

Motivasi dan disiplin kerja berpengaruh signifikan terhadap kinerja pegawai dengan diperoleh persamaan regresi $\mathrm{Y}=$ $8,586+0,387 \mathrm{X} 1+0,405 \mathrm{X} 2$, nilai korelasi sebesar 0,753 atau memiliki hubungan yang kuat dengan kontribusi pengaruh sebesar $56,7 \%$ sedangkan sisanya sebesar 43,3\% dipengaruhi faktor lain. Pengujian hipotesis diperoleh nilai $\mathrm{F}$ hitung $>\mathrm{F}$ tabel atau $(43,928>2,740)$. Dengan demikian hipotesis ketiga yang diajukan bahwa terdapat berpengaruh signifikan antara motivasi dan disiplin kerja terhadap kinerja pegawai diterima.

\section{PENUTUP}

\section{Simpulan}

1. Motivasi berpengaruh signifikan terhadap kinerja pegawai dengan kontribusi pengaruh sebesar $42,4 \%$. Uji hipotesis diperoleh nilai $\mathrm{t}$ hitung $>\mathrm{t}$ tabel atau $(7,071>1,995)$.

2. Disiplin kerja berpengaruh signifikan terhadap kinerja pegawai dengan kontribusi pengaruh sebesar $42,7 \%$. Uji hipotesis diperoleh nilai thitung $>\mathrm{t}$ tabel atau $(7,112>1,995)$.

3. Motivasi dan disiplin kerja berpengaruh signifikan terhadap kinerja pegawai dengan kontribusi pengaruh sebesar $56,7 \%$ sedangkan sisanya sebesar $43,3 \%$ dipengaruhi faktor lain. Uji hipotesis diperoleh nilai $\mathrm{F}$ hitung $>\mathrm{F}$ tabel atau $(43,928>2,740)$.

\section{Saran}

1. Pimpinan harus menegakkan peraturan dengan baik sesuai dengan ketentuan yang berlaku guna menjamin karyawan diperlakukan dengan adil.

2. Perusahaan harus selalu memberikan semangat dan apresiasi yang layak untuk memastikan karyawan memiliki semangat kerja yang tinggi.

3. Kinerja perusahaan dapat ditingkatkan dengan memberdayakan karyawan dengan menegakkan peraturan yang baik dan pemberian motivasi yang lebih inten lagi. 
DAFTAR PUSTAKA

Affandi, A. (2020). Optimization of MSMEs Empowerment in Facing Competition in the Global Market during the COVID-19 Pandemic Time. Systematic Reviews in Pharmacy, 11(11), 1506-1515.

Akbar, I. R., \& Wiguna, M. (2020). Hubungan Motivasi Terhadap Prestasi Kerja Guru Pada SMK YAPIA Parung, Kab. Bogor. JENIUS (Jurnal Ilmiah Manajemen Sumber Daya Manusia), 4(1), 61-69.

(2020). Pengaruh Motivasi Terhadap Kinerja Karyawan Pada Pt. Unggul Abadi Di Jakarta. Jurnal Ekonomi Efektif, 3(1).

Algifari. (2015). “Analisis Regresi untuk Bisnis dan Ekonomi". Purwakarta: BPFE.

AM, E. N., Affandi, A., Udobong, A., \& Sarwani, S. (2020). Implementation of Human Resource Management in the Adaptation Period for New Habits. International Journal of Educational Administration, Management, and Leadership, 19-26.

Arikunto, Suharsimi (2014). "Prosedur Penelitian Suatu Pendekatan Praktek". Jakarta: Rineka Cipta.

Edi Sutrisno (2016). Manajemen Sumber Daya Manusia. Jakarta: Prenadamedia Group.

Effendy, A. A., Sunarsi, D., Kristianti, L. S., Irawati, L., \& Wahyitno, W. (2020). Effect Of Giving Reward and Motivation to Employee Productivity In PT. Sinar Kencana Jaya In Surabaya. HUMANIS (Humanities, Management and Science Proceedings), 1(1).

Freed Luthans (2016) Organizational Behavior, McGraw-Hill, New York.

Gerry Dessler (2016) Human Resources Management, Prenticehall, London: International Inc.

Handoko (2016) Manajemen Personalia dan Sumberdaya Manusia. Purwakarta: BPFE.

Hasibuan (2016) “Manajemen Sumber Daya Manusia”. Haji Masagung. Jakarta.
Henry Simamora (2005), Manajemen Sumber Daya Manusia, STIE YKPN Bandung.

Imam Ghozali (2017). "Aplikasi Analisis Multivariate Dengan Program SPSS". Edisi Kelima. Semarang: Badan Penerbit Undip.

Istijanto (2014) "Riset Sumber Daya Manusia". Jakarta: PT. Gramedia Pustaka

Jasmani, J. (2019). Pengaruh Product Development Dan Promotion Mix Terhadap Peningkatan Penjualan Yang Berdampak Pada Keunggulan Bersaing. Jurnal Ekonomi Efektif, 1(2). (2020). The Influence of Product Mix, Promotion Mix and Brand Image on Consumer Purchasing Decisions of Sari Roti Products in South Tangerang. PINISI Discretion Review, 1(1), 165-174.

Kartini Kartono (2011) Pemimpin dan Kepemimpinan, Jakarta: PT. Rajawaligrafindo Persada.

Mangkunegara, Anwar Prabu, 2008. "Manajemen Sumber Daya Manusia Perusahaan, cetakan pertama". Penerbit: Remaja Rosdakarya, Bandung

Mani, J. (2018). Pengaruh Peran Nilai Pelanggan Dan Citra Merek Terhadap Kinerja Pemasaran. Jurnal Mandiri, 2(2), 263-280.

Nitisemito, Alek.S, (2010), Manajemen Personalia, Ghalia Indonesia, Jakarta.

Nurjaya, N., Affandi, A., Erlangga, H., Sunarsi, D., \& Jasmani, J. (2021). The Effect of Product Promotion and Innovation Activities on Marketing Performance in Middle Small Micro Enterprises in Cianjur. Budapest International Research and Critics Institute (BIRCI-Journal): Humanities and Social Sciences, 4(1), 528-540.

(2020). The Effect of Work Stress and Work Conflict on Employees Turnover Intention In Middle Small Micro Enterprises (MSMEs) In South Tangerang Region. International Journal of Educational 
Administration, Management, and Leadership, 51-62. (2020). Edupreneurship management in shaping the nation's character. Jurnal Konseling dan Pendidikan, 8(3), 198-206.

(2021). Pengaruh Etos Kerja Dan

Disiplin Kerja Terhadap Kinerja Pegawai Pada Dinas Kehutanan Dan Perkebunan Kota Bogor. JENIUS (Jurnal Ilmiah Manajemen Sumber Daya Manusia), 4(2), 172-184.

Pranoto, P., Jasmani, J., \& Marayasa, I. N. (2019). Pelatihan Digital Marketing Untuk Peningkatan Perekonomian Anggota Karang Taruna Al Barkah Di Kampung Cicayur-Tangerang. Jurnal Pengabdian Dharma Laksana, 1(2), 250-258.

Rivai Veithzal (2015) Manajemen Sumber Daya Manusia Untuk Perusahaan. Jakarta: PT Raja Grafindo Persada.

Santoso, Singgih (2015). "Menguasai Statistik Multivariat". Jakarta: PT Elex Media Komputindo.

Sedarmayanti (2016) Manajemen Sumber Daya Manusia, Reformasi Birokrasi dan Manajemen Karyawan Negeri Sipil, Cetakan Kelima, Bandung: PT Refika Aditama.
Siagian, S (2007). Manajemen Sumber Daya Manusia. Jakarta: Bumi Aksara.

Sinamo, J. (2011). Delapan Etos Kerja Profesional. Jakarta: Institut

Sofyan, S., Prasada, D., \& Akbar, I. R. (2020). Pengaruh Motivasi, Lingkungan Kerja dan Kepuasan Kerja Terhadap Kinerja Guru SMP/MTs Muhammadiyah. Jurnal Ilmu Komputer dan Bisnis, 11(2a), 44-55.

Sudjana (2014) "Metode Statistika", Bandung: Tarsido.

Sugiyono (2017), “Metode Penelitian Administrasi: dilengkapi dengan Metode R \& D". Bandung: Alfabeta.

Sunarsi, D., Rohaeni, . N., Wulansari, . R., Andriani, . J., Muslimat, . A., Rialmi, . Z., Kustini, . E., Kristianti, . L. S., Rostikawati, . D., Effendy, . A. A., Purwanto, . A. \& Fahlevi, . M. (2020) Effect of e-Leadership Style, Organizational Commitment and Service Quality towards Indonesian School Performance. Systematic Reviews in Pharmacy, 11 (10), 472481. doi:10.31838/srp.2020.10.71. 